\title{
Does Power Justify Rape? - Examining Social Behavior and Related Concepts
}

\author{
Anmol Singh Khanuja \\ $3^{\text {rd }}$-year Law Student at Narsee Monjee Institute of Management Studies, Navi Mumbai, Maharashtra, India
}

Corresponding author: ask290999@gmail.com

Received: $14-03-2020$

Revised: $12-08-2020$

Accepted: 24-09-2020

\begin{abstract}
Power, according to some is considered to be a possibility to influence others, some say it is something which entrenches control over others, some say it is something which promotes people to take action and facilitate decision making and planning. But many a time this power is used or misused in enabling or disabling an individual from doing or performing certain things. Thus, this paper aims to do an in-depth examination of the relationship between power and Rape, this paper aims to put forth certain theories which are concerning the commission of Rape. Furthermore, this paper aims to apprise the reader by conflating the sociological, psychological, and political impacts and consequences in a subtle way.
\end{abstract}

Keywords: Rape, Indian Society, Behavior, Power, Theories

Violence against women is not a recent concept that exists in our society, it has existed since 300-400 BC, which has led to many reforms for them but those reforms were amended with the change in time and thinking process of the society. Talking about Indian society, reforms have existed but the bad part is that we haven't followed those reforms genuinely. India is a country where women are preached as goddesses but there also exist several women who are subjected to violence in everyday life, this violence has led to the rise of many social reformers who envisaged a better India for a woman to live. But there always exists a behavior which keeps the society away from making progress. Among the offences related to violence against women, there exist offences of sexual violence against women and among sexual violence exists a concept or offence of Rape, Rape is considered to be the most heinous crime against any women.
Violence against women as adopted by UNGA, 1993 means that ANY ACT OF GENDER based violence which results in any kind of suffering, whether it is psychological or sexual suffering, these all things include the threat of doing such acts or any kind of coercion which anyway hampers the liberty of the woman.

Sexual violence is something where there is an attempt being made to commit a sexual act, that is unwanted by the woman or to which she hasn't consented to, by the method of coercion, which includes threat or any kind of undue influence like unwanted sexual comments or advances, etc.

Rape is considered to be the most heinous crime against any woman and a crime against society because it

How to cite this article: Khanuja, A.S. (2020). Does Power Justify Rape? Examining Social Behavior and Related Concepts. Int. J. Soc. Sci., 9(03): $127-$ 132. 
portrays the approach of society towards women. Section 375 of the Indian Penal Code, 1860 defines Rape, though there exist a lot of loopholes in the definition which includes the exclusion of marital Rape, gender neutrality of the section (we still believe that only man can commit Rape and not a woman), less information or description about pedophiles, etc.

Looking at the statistics of the cases registered in India, in 2001 there were around 16000 which means 43 (approx.) cases per day. In 2009, the numbers went up by around 5000 bringing the 43 per day to 57 (approx.) per day and finally looking at the recent data i.e. data of 2018, in 2018 India had around 33000 cases of Rape registered which brings the daily count to 90 (approx.) cases per day.

Fathoming the data leaves us with 2 points, $1^{\text {st }}$ being the increase in the actual cases, $2^{\text {nd }}$ is the increase in cases reported. An increase in cases portrays that we lack in many things, that I will discuss in further sections. $2^{\text {nd }}$ is there is an increase in awareness, earlier or even today, there exist many unreported cases but the awareness of reporting has increased when we compare \& categorize it with the earlier data, the increase in both the cases is a matter of grave concern because it is not the India that our visionary leaders thought of.

Mahatma Gandhi in his works (constructive program, pg. 17-18) has argued that men have not realized the importance of women in their lives and that they're still taught to be slaves of their men and are asked for dowry which is again directly or indirectly linked with the caste system, these are the things that our society should get rid of and that they should accept a view where "woman is the companion of man, gifted with equal mental capability" (Speeches and Writings of Mahatma Gandhi, p, 425).

But have we moved in the same way that our leaders wanted? or we've moved far away from those thoughts, this is determined by the societal behavior, behavior which has generated through certain customs or practices. Behavior which impacts the state of mind of an individual.

\section{Societal Behavior}

There exist many points but I'll be explaining a few:
* As it is said that development of an Individual starts from the early ages of life, so the thing which is taught in early ages impacts an individual and stays for a longer period, parents bring up their child by giving feminine toys and when she grows to an adult she finally loves baby dolls over truck toys, boys are taught to masculine things like boys are not required to take permission when they need to go out to play but girls are required to. Schools and neighbourhood too play a lot of roles through peer group structure, homophobic speech. (Connell and Messersshmidt 2005). These things create lack of confidence among them that allows the male to exercise power over his wife, daughter, sister, and to some extent mother, and then this exercise of power becomes a base for Domestic violence. This concept is known as 'learned helplessness'. (Rao 2015).

* Child marriage; marriage at early ages (18-24): the concept of Child Marriage may have relinquished from the urban areas but it does exist in rural areas, where a man of 20-25 years is married to Young girls, these things cause extraordinary sufferings for the girl child, like early age pregnancies, etc. exposing them to many physical and mental disorders (Rao 2015)

* Beating a woman, under the influence of alcohol or for any wrong committed by her, there exist men even in the upper strata of the society who usually beat their partners. In some areas beating a woman is considered to be a normal activity which justifies masculinity over the woman; I quote a famous quote 'Vo mard hi kya jo mare na' meaning thereby what kind of a man he is if he doesn't hit.

* Maximum Indian women are usually seen as emotional caretakers who are obliged to take care of the Parents of his husband, wash clothes, make food for all, and does the cooking work.

* The hypocrisy comes to picture when women are also seen as an honor of a particular family for example; if a daughter of a high-class family runs away with a lower caste man, that is seen to be a huge dishonor to the woman's family. 
* The caste system, this is something that is the most debated issue; there have been cases where women of upper caste can deny sex as compared to the ones who belong to the lower class. There also have been instances where men of upper caste have raped women of lower caste. (Prem Chowdhary 2015).

* There have been cases of men being called as Namard if the man doesn't possess bravery, adequate sexual power or courage to promote violence (Marsh and Campbell 1982, 145-146).

* There also exist people in society who think that boys and girls roaming freely together increases the number of crimes in the society.

* The division in men or the subordination or exclusion of some homosexual men has led to the development of hegemonic masculinity like showing masculinity over the LGBTQIA++ community (Connell and Messershmidt 2005).

* It is a general behavior that men and women both are choosier like women are 'choosier' in mate selection than men, meaning that they are less interested in pursuing casual sex without commitment whereas Men are much choosier in selecting wives than they are in selecting 'one-night stands' (Browne 2006).

* The friendly nature of a woman is unpalatable, for example, women who drink alcohol or women who chat openly with men or with society are unaccepted sometimes.

* Society doesn't understand or will believe that if a woman has called a man to her house, or to any place then if that man Rapes the woman then the society won't believe because she was the person who called (Baker 1999).

* Advertisements cause a lot of disturbance in the minds of those who are unable to handle lustful ads or vulgar movies and songs. This creates imagery in the minds of the persons leading to the commission of the crime (Gangrade, Sooryamurthy, Radhamany and Renjini 1995).

* There exists a diaspora that believes in sex

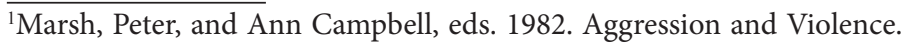
Oxford: Basil. determination, people want to get satisfied that they are getting a male child if they aren't then this leads to infanticide (Chowdhary 2015).

* Brahmanical Patriarchal society; this concept has originated from the rule by princely groups, the system of sati, etc. these kinds of activities promote things like a widow cannot remarry (Chapman 2014).

* There exist many Rape myths in the society which justifies male sexual aggression against women like women enjoy being Raped, women could avoid Rape, etc. (Kamdar, Kosambiya, Chawada, Verma and Kapadia 2017 and Sarkar 2013).

* A certain amount of allowance given by women to men to exercise power or dominance over them is a social behavior that doesn't allow society to change.

* There exists no Marital Rape is another argument presented by some politicians.

\section{Behavior that has determined certain theories related to Rape}

\section{Evolutionary theory}

The scholars believe that this the domination of men is an evolutionary concept where survival of the fittest the principle, this fitness is related to reproduction where the definition of proportional parental involvement is the answer to the disparity between male and female natures is found. Also, the scholars say that many of the challenges are the same for both sexes, who need to get adequate food and water, be safe from temperature fluctuations, and escape predators. However, when it comes to marriage, members of the two sexes experience very different challenges, resulting in differences not only physical but also psychological. (Stephen Gold 1996)

\section{Biological theory}

The scholars here argue that Rape is a biological thing where a man, possesses the biological power to exercise dominance over a woman because the reproductive health of a male is higher than the female, also the increase in testosterone levels leads to the increase in dominance behavior of the male (Thornhill 1999). 


\section{Motivational Theory}

This is also known as the commodity theory where sex is believed to be the commodity, now this motivates the offender to obtain that commodity, if he is not able to obtain it, then he will steal it (Baker 1997).

\section{Synthesized theory}

This theory is a combination of the above 2 i.e. Motivational and Biological, here Sex drive and Power to control a woman plays a major role coupled with sexual imagery (Bart, Lee, Pauline \& Ellis 1991).

\section{Gender Motivated crime}

Some theorists also believe that Rape is a gendermotivated crime i.e. the hate that the male child or a Male individual develops during his course of life in the form of discrimination, love, special women and child development policies, etc. These things are usually faced in workplaces, public places, etc. (Goldschied 1999).

\section{Radical feminist theory}

Here it is believed that Rape is a kind of terrorism that increases the dependency of women over men, it is also believed here that rapist is not an individual but the whole political system which is based on patriarchal values (Ghosal 2009).

\section{Social Learning theory}

As the name suggests, an Individual learns to commit the offence when that individual sees and feels those circumstances in real life like home or neighborhood.

\section{These theories describe some determinants}

Hegemonic Masculinity: This is a historical concept and there is no means that this concept goes away instantly, it will fade away as the society becomes more progressive, it is also a proven fact that the males are more prone towards commission of crime, this commission of the crime is backed by their masculinity. People start by seeing their parents beating and exercising power over mother, these tendencies develop the child in a similar way.
Dominance: Theorists also believe that sexual harassment or Rape is not just about sex it is about power, this power is backed by their behavior or by biological levels like increase in testosterone levels and sometimes there exist some societies where the society has followed the ideology of male superiority, these things also provoke a man to go for the commission (Sanday, P. 1981) ${ }^{2}$.

Gender racism: Rape as a gender-motivated crime as discussed above in theories.

Anti-Social behavior: Men with anti-social behavior stay aloof from society that may be a cause for the commission of Rape, also men with Low economical background, Low IQ level or maniacs are prone to these activities (Gangrade, Sooryamurthy, Radhamany and Renjini 1995).

Deterioration of Marital relationships like unavailability of partners, illness of spouse can contribute to the commission of these crimes (Gibbons 1968) ${ }^{3}$.

Communal differences: with time the conflict between Upper caste has not decreased but has increased this has led to some uncontrollable events like upper caste people raping women of lower caste in Haryana, these things are still prevalent but aren't reported.

Sex drive/ uncontrollable desire: Many men Rape because of sexual desire coupled with esteem (Baker 1999).

Alcohol consumption: it is a proven fact that alcohol has played a major role in the commission of these crimes example: that date Rapes are due to alcohol consumption (Chattoraj 2007)

State's negligence in terms of Infrastructure like lighting in streets or Investigation by police, also there has been many incidents of Custodial Rapes like the Mathura Rape Case 1972, case of Rameeza bee 1979, case of Maya Tyagi 1980 and many more cases which goes unreported today (Dutta and Sircar 2013).

\footnotetext{
2 Sanday, P.R. (1981), The Socio-Cultural Context of Rape: A Cross Cultural Study. Journal of Social Issues, 37: 5-27.

${ }^{3}$ Gibbons, Don C. (1968) society, crime and criminal careers, Prentice hall, New Jersey.
} 
Judicial process: The slow process in the judiciary also encourages the offenders to commit the crime, the stand of the judiciary is a bit unstable as no one can predict the outcome (Gangoli 2011).

Abuse to women Politicians: There has been a significant increase in the kind of things that have and will discourage women's participation in politics and the judiciary. (Amnesty International India 2020)

\section{Impact on the victim}

\section{Agony can be mental or physical}

* Humiliation and Anti-Social behavior: society wouldn't empathize with the victim, won't understand what is going in the mind of the victim, statements like don't marry her would be heard first, acceptance in the society would be comparatively less due to the societal behavior I stated above (Chattoraj 2007).

* Development of a sense of Distrust; distrust towards the society as this fear of Rape prevents the very woman from participating in the events in public life, distrust of the law enforcement and state, distrust on itself which will lead to suicidal consequences (Gangoli 2011).

* Physical consequences like unwanted pregnancy, sexually transmitted infections, unsafe abortions, and sometimes suicidal tendencies.

* Mental consequences like Rape trauma, posttraumatic stress like depression, fatigue, nightmares or flashbacks (WHO guidelines 2003).

So, if any society wants to improve then it should focus on the above points because it is the victim who is important, we Indians should focus on mental health because it is the least focused part by ourselves, we still think that Mental is no problem.

\section{CONCLUSION}

Some of the common reasons in the commission of any crime could be an increase in the number of population and the Inequality in society. A large number of people turn hostile against Police like a medical practitioner refraining from providing proper medical evidence if something is alleged against the Police because it is Police. Women at workplaces also get dominated by senior officers to provide them sexual pleasures to get promoted. What India should improve at is the societal problem, People, if there's a Rape committed, folks will demand Justice in a form of hard Punishment for the Offender(s) but we fail to improve society's attitude towards the victim or a woman. A nation-wide program should be organized like the Men's action to stop violence against women (MASVAW) was organized in UP in 2002 which helped the men understand the women because men and women can act as allies to dismantle the hierarchal gender regimes. I also believe that in the past and the present, the feminists have been successful in demanding strict laws against the accused but their revolution have also led to division of the society into a gender-specific thing which is also bad as these acts again create Gender Racism because Rape many a time is something that one does out of revenge (which may be personal or is a result of depression), the demand for stricter laws for the Offender has given chance to law enforcement to determine women's sexuality. Thus, the approach should change and that approach should be pro-victim in nature. Moreover, when we talk about laws, we should not only try to control or curb Rape but we should also aim to denigrate the unconscious power exercised by the wrongdoer and that should be backed by education and that to a modern progressive education, where the idea of Rape doesn't even come in anybody's mind.

\section{REFERENCES}

Amnesty International India. 2020. Troll Patrol India Exposing Online Abuse Faced by Women Politicians in India, linkhttps://amnesty.org.in/wp-content/uploads/2020/01/TrollPatrol-India-Findings.pdf

Baker, Katharine. 1997. Once a Rapist? Motivational Evidence and Relevancy in Rape Law, 110 Harv. L. Rev. 563.

Baker, Katharine. 1999. What Rape Is And What It Ought Not To Be, American Bar Association, Jurimetrics, 39(3): 233-242.

Bart, P. and Ellis, L. et al. 1991. Theories of Rape: Inquiries into the Causes of Sexual Aggression, Contemporary Sociology, 20: 268.

Browne, Kingsley. 2006. Sex, Power, and Dominance: The Evolutionary Psychology of Sexual Harassment, Managerial and Decision Economics, Evolutionary Psychology and Management, 27(2/3): 145-158. 
Chapman, Jean. 2014. Violence against Women in Democratic India: Let's Talk Misogyny, Social Scientist, 42(9/10: 49-61.

Chattoraj, B. 2007. Sex Related Offences and Their Prevention and Control Measures: An Indian Perspective pp. 82-99, annual report for 2006 and resource material series No. 72, United Nations Asia and Far East Institute for the Prevention of Crime and the Treatment of Offenders (UNAFEI).

Chowdhry, Prem. 2015. Popular Perceptions of Masculinity in Rural North Indian Oral Traditions, Nanzan University, Asian Ethnology, 74(1): 5-36.

Connell, R. and Messerschmidt, James, et al. 2005. Hegemonic Masculinity: Rethinking the Concept, Sage Publications, Gender and Society, 19(6): 829-859.

Dhawan, Himanshi. 2014. Rape every 30 minutes in India, Times of India. URL: https://timesofindia.indiatimes.com/india/Onerape-every-30-minutes-in-India/articleshow/39128982.cms.

Dutta, D. and Sircar, O. et al. 2013. India's Winter of Discontent: Some Feminist Dilemmas in the Wake of a Rape, Feminist Studies, 39(1): 293-306.

Gangoli, Geetanjali. 2011. Controlling women's sexuality: Rape law in India, International approaches to Rape, Bristol University Press, Policy Press.

Gangrade, K., Sooryamoorthy, R. and Renjini, D. et al. 1995. Child Rape: facets of a heinous crime. Social Change, 25: 161-76.

Ghosal, Sarbani. 2009. Socio-Political Dimensions of Rape, the Indian Journal of Political Science, 70(1): 107-120.

Gold, Stephen. 1996. Review of Sex, Power, Conflict: Evolutionary and Feminist Perspectives, Edited by David M. Buss and Neil M. Malamuth. Oxford University, Press, New York.
Goldscheid, J. 1999. Gender-Motivated Violence: Developing a Meaningful Paradigm for Civil Rights Enforcement, 22 HARV. Women's L.J.

Harris, Gardiner, 2013. For Rape Victims in India, Police Are Often Part of the Problem, the New York Times.

Kamdar, Z., Kosambiya J., Chawada B., Verma, M. and Kadia, A. et al. 2017. Rape: Is it a lifestyle or behavioral problem? Indian J. Psychiatry, 59: 77-82.

Mogford, E., Irby, C. and Das, A. et al. 2015. Changing men to change gender: Combatting hegemonic masculinity through Anti-violence activism in India, International Journals, International Journal of Sociology of the Family, 41(2): 71-93.

Rao, G., Vidya, K. and Sriramya, V. et al. 2015. The Indian "girl" psychology: A perspective. Indian J. Psychiatry, 57: 212-5.

Rape cases in India have more than doubled since 2001 on November 13, 2015, Scroll report, URL: https:/scroll.in/ latest/800033/rape-cases-in-india-have-more-than-doubledsince-2001-says-report.

Sarkar, J. 2013. Mental health assessment of Rape offenders. Indian J. Psychiatry, 55: 235-43.

Thornhill, Randy. 1999. The Biology of Human Rape, Jurimetrics, 39(2): 137-47.

Who Guidelines for Medico-Legal Care for Victims of Sexual Violence. 2003. Chapter 2 Sexual violence: prevalence, dynamics and consequences, ISBN 924154628X. 